\title{
Removal of Arsenite from Water by Ce-Al-Fe Trimetal Oxide Adsorbent: Kinetics, Isotherms, and Thermodynamics
}

\author{
Cuizhen Sun, ${ }^{1,2,3}$ Jinwei Qiu, ${ }^{1}$ Zhibin Zhang, ${ }^{1,4}$ Taha F. Marhaba, ${ }^{1,3}$ and Yanhao Zhang ${ }^{1}$ \\ ${ }^{1}$ School of Municipal and Environmental Engineering, Shandong Jianzhu University, Jinan, Shandong 250101, China \\ ${ }^{2}$ Co-Innovation Center of Green Building, Jinan, Shandong 250101, China \\ ${ }^{3}$ John A. Reif, Jr. Department of Civil and Environmental Engineering, New Jersey Institute of Technology, Newark, NJ 07102, USA \\ ${ }^{4}$ Center for Sustainable Development \& Global Competitiveness, Stanford University, Stanford, CA 94305, USA
}

Correspondence should be addressed to Zhibin Zhang; zhibin_zhangsd@126.com and Taha F. Marhaba; marhaba@njit.edu

Received 25 March 2016; Accepted 19 June 2016

Academic Editor: José Morillo Aguado

Copyright (c) 2016 Cuizhen Sun et al. This is an open access article distributed under the Creative Commons Attribution License, which permits unrestricted use, distribution, and reproduction in any medium, provided the original work is properly cited.

Ce-Al-Fe trimetal oxide adsorbent was prepared. The morphology characteristics of the new adsorbent were analysed by the transmission electron microscope (SEM) method. The SEM results implied its ability in the adsorption of As (III). To verify the analyses, bench-scale experiments were performed for the removal of As (III) from water. In the experiments of adsorption, As (III) adsorption capacity of the trimetal oxide adsorbent was presented significantly higher than activated aluminium oxide and activated carbon. As (III) adsorption kinetics resembled pseudo-second-order adsorption mode. When initial As (III) concentration was 3,8 , and $10 \mathrm{mg} \cdot \mathrm{L}^{-1}$, the maximum adsorption capacity achieved was $1.48,3.73$, and $5.12 \mathrm{mg} \cdot \mathrm{g}^{-1}$, respectively. In addition, the experimental adsorption data were described well by the Freundlich adsorption isotherm model at 20,30 , and $40^{\circ} \mathrm{C}$. The enthalpy change $(\Delta S)$, the standard free energy $(\Delta G)$, and entropy change $(\Delta H)$ indicated that the nature of As (III) adsorption was exothermic and spontaneous with increasing randomness on the interface of solid and liquid. And the adsorption mechanism can be interpreted as chemisorption with As (III) multilayer coverage formation on the adsorbent surface.

\section{Introduction}

Arsenic contamination of water, resulting from both natural processes and anthropogenic activities [1-3], has a great harm to human health and other living organisms due to the arsenic carcinogenicity and toxicity $[4,5]$. In natural water, inorganic arsenic predominantly exists in two forms of As (III) and As (V) [6]. Compared with the latter, the former presented 2560 times higher toxicity and is more mobile [7]. As (III) exists widely in sediment, surface water, and groundwater. Due to the existence of the reducing condition, the concentrated As (III) is released from sediment into water and this happened almost constantly [8-10]. Therefore, As (III) removal is becoming one of the hot topics in pollution incident emergency treatment and drinking water treatment researches.

Several technologies including adsorption [11], coagulation/precipitation [12], and ion exchange [13] have been used to remove As (III) from polluted surface water and water resources. When $\mathrm{pH}$ varied from weakly acidic to weakly alkaline in natural water, the hydrolyzed species of As (III) existed mainly in the form of nonionic $\mathrm{H}_{3} \mathrm{AsO}_{3}[8,14]$. For the removal of As (III), coagulation/precipitation technology is generally not effective at natural $\mathrm{pH}$ [15] because of As (III) uncharged form. Adsorption is considered as one of the most promising methods for As (III) removal due to high removal efficiency without yielding by-products. The key component of adsorption processes is the adsorbents that are expected to have high adsorption capacities toward As [16]. Some investigations already reported that the composite oxides adsorbents based on iron [17], titanium [18], manganese and alumina oxide $[19,20]$, Fe-Ni binary oxide [21], and $\mathrm{Fe}-\mathrm{Cu}$ binary oxide [22] are effective for As removal. However, these adsorbents have relatively low adsorption capacity for As, and iron oxide-based adsorbent has received great attention due to the binding affinity for inorganic As and relatively low production costs [23-25].

In recent years, hydrous cerium $(\mathrm{Ce})$ oxide has been developed as a new adsorbent for arsenate [26], fluoride [27], 
and phosphate removal [28] with high adsorption capacity $[29,30]$. But the high cost of Ce limits its use. Therefore, a low cost adsorbent with high adsorption capacities of arsenic is desirable. Recently, many researchers successfully developed cerium-based bimetal oxide adsorbents, such as Ce-Ti [31, 32] and Fe-Ce [33]. The results indicated a remarkably higher adsorption capacity of As (V) than many reported adsorbents. However, the removal efficiency for As (III) is less than $58 \%$.

In this work, a new Ce-Al-Fe trimetal oxide adsorbent, prepared by mixing iron, cerium, and aluminium oxides, was applied to remove As (III) from water to increase the adsorption capacity. Its adsorption capacity of As (III) was evaluated in comparison with commercial materials. The batch adsorption behaviors are including adsorption kinetics, isotherms, and thermodynamics.

\section{Experiments}

2.1. Adsorbent Preparation. At room temperature, $\mathrm{AlCl}_{3} \cdot 6 \mathrm{H}_{2} \mathrm{O}$, $\mathrm{Ce}\left(\mathrm{SO}_{4}\right)_{2} \cdot 4 \mathrm{H}_{2} \mathrm{O}$ (analytical grade, Binzhou Kun Bao Chemical Co., Ltd., China), and $\mathrm{FeCl}_{3} \cdot 6 \mathrm{H}_{2} \mathrm{O}$ were dissolved with deionized water and the $\mathrm{Al} / \mathrm{Fe} / \mathrm{Ce}$ molar ratio of water is $2: 1: 0.2,1: 2: 0.2,2: 1: 0.5,1: 2: 0.5,2: 1: 1.5$, and $1: 2: 1.5$. At $200 \mathrm{rpm}$, the $\mathrm{pH}$ was adjusted to 10 by $6 \mathrm{M} \mathrm{NaOH}$ solution. After aging of $12 \mathrm{~h}$, the precipitates were collected and washed using distilled water. Finally, the precipitates were dried at $70^{\circ} \mathrm{C}$ for $12 \mathrm{~h}$.

2.2. Adsorption Experiments for As (III). The experiment water was prepared by diluting stock solution containing $1000 \mathrm{mg}$-As $\cdot \mathrm{L}^{-1}$, which was prepared by dissolving $\mathrm{NaAsO}_{2}$ in deionized water. $2 \mathrm{~g} \cdot \mathrm{L}^{-1}$ adsorbent granule was added into the water of $100 \mathrm{~mL}$. The mixture was shaken at $150 \mathrm{rpm}$ and $25^{\circ} \mathrm{C}$ for a long time. Then, the samples were taken and filtered through a membrane of $0.45-\mu \mathrm{m}$, and the residual arsenite was determined on an Atomic Absorption Spectrophotometer (ABS-990, Beijing Purkinje General Instrument, China). In the investigation of adsorption kinetics, the initial arsenic concentrations were 3,8 , and $10 \mathrm{mg} \cdot \mathrm{L}^{-1}$. When As (III) initial concentration varied from 1 to $50 \mathrm{mg} \cdot \mathrm{L}^{-1}$, the adsorption isotherms were studied. All experiments were conducted in three times, and all data were the average value.

The adsorption capacity was presented in

$$
\begin{aligned}
& q_{e}=\frac{\left(C_{0}-C_{e}\right) \cdot V}{m}, \\
& q_{t}=\frac{\left(C_{0}-C_{t}\right) \cdot V}{m},
\end{aligned}
$$

where $q_{t}\left(\mathrm{mg} \cdot \mathrm{g}^{-1}\right)$ and $q_{e}\left(\mathrm{mg} \cdot \mathrm{g}^{-1}\right)$ are the adsorption capacity at time $t(\mathrm{~min})$ and at equilibrium and $C_{e}\left(\mathrm{mg} \cdot \mathrm{L}^{-1}\right)$ and $C_{0}$ $\left(\mathrm{mg} \cdot \mathrm{L}^{-1}\right)$ are equilibrium and initial As (III) concentration. At time $t$, the concentrations of As (III) $\left(\mathrm{mg} \cdot \mathrm{L}^{-1}\right)$ are $C_{t}$. And $m(\mathrm{~g})$ is the adsorbent granule weight, and $V(\mathrm{~L})$ is the water volume.

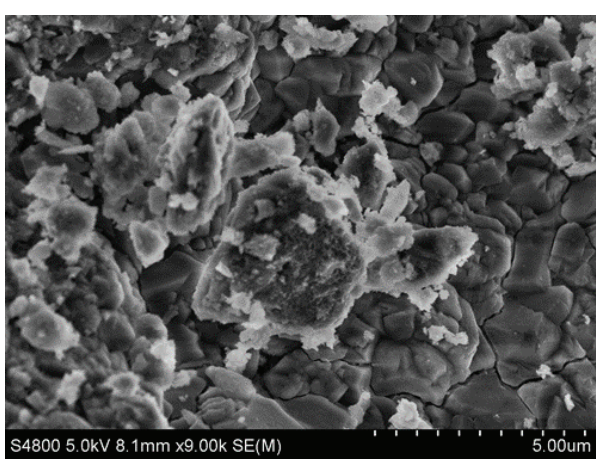

FIGURE 1: SEM images of Ce-Al-Fe trimetal oxide adsorbents $(\mathrm{Al} / \mathrm{Fe} / \mathrm{Ce}$ molar ratio $=1: 2: 0.5)$.

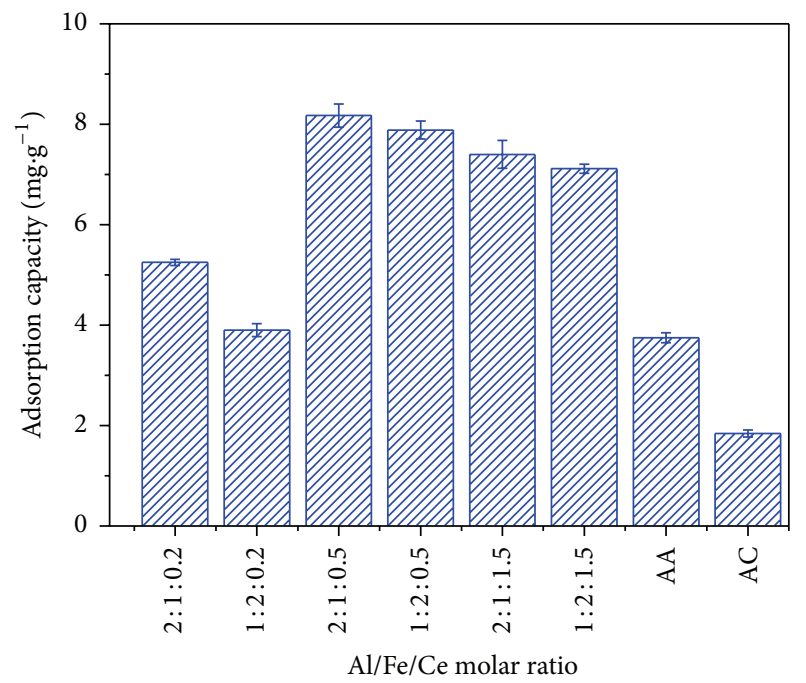

FIGURE 2: As (III) adsorption capacity onto Ce-Al-Fe trimetal oxide adsorbents with different $\mathrm{Al} / \mathrm{Fe} / \mathrm{Ce}$ molar ratio $(\mathrm{pH}=7.0$, initial concentration of As (III) $=20 \mathrm{mg} \cdot \mathrm{L}^{-1}$, the temperature $=25 \pm 1^{\circ} \mathrm{C}$, and adsorbent dosage $\left.=2 \mathrm{~g} \cdot \mathrm{L}^{-1}\right)$.

\section{Results and Discussion}

3.1. Morphology of Ce-Al-Fe Trimetal Oxide Adsorbent. The SEM image of Ce-Al-Fe trimetal oxide adsorbents is shown in Figure 1.

Tiny uniformly distributed pores were present on the surface of Ce-Al-Fe trimetal oxide adsorbent. For adsorption, a large surface area was supported by this porous structure with great potential for the removal of As (III).

3.2. Comparison with Other Commercial Adsorbents. Figure 2 illustrates As (III) adsorption capacity onto the adsorbent with different $\mathrm{Al} / \mathrm{Fe} / \mathrm{Ce}$ molar ratio $(2: 1: 0.2,1: 2: 0.2$, $2: 1: 0.5,1: 2: 0.5,2: 1: 1.5$, and $1: 2: 1.5)$ and the capacities were compared with commercial adsorbents.

The adsorption capacities of As (III) on activated aluminium oxide (AA) and activated carbon (AC) were 3.75 and $1.84 \mathrm{mg} \cdot \mathrm{g}^{-1}$, respectively. And the responding As (III) removal percent was $37.5 \%$ and $18.4 \%$. Regardless of the $\mathrm{Al} / \mathrm{Fe} / \mathrm{Ce}$ molar ratio, Ce-Al-Fe trimetal oxide adsorbents 
TABLE 1: The kinetic parameters for the pseudo-first-order, pseudo-second-order, and intraparticle diffusion model at different initial As (III) concentrations and $25^{\circ} \mathrm{C}$.

\begin{tabular}{|c|c|c|c|c|}
\hline \multirow{2}{*}{ Kinetic models } & \multirow{2}{*}{ Parameters } & \multicolumn{3}{|c|}{$C_{0}\left(\mathrm{mg} \cdot \mathrm{L}^{-1}\right)$} \\
\hline & & 3 & 8 & 10 \\
\hline \multirow{4}{*}{ Pseudo-first-order } & $q_{e, \exp }\left(\mathrm{mg} \cdot \mathrm{g}^{-1}\right)$ & 1.225 & 3.273 & 4.097 \\
\hline & $k_{1}\left(\mathrm{~h}^{-1}\right)$ & 0.048 & 0.038 & 0.031 \\
\hline & $q_{e, \mathrm{cal}}\left(\mathrm{mg} \cdot \mathrm{g}^{-1}\right)$ & 0.905 & 1.300 & 1.440 \\
\hline & $R^{2}$ & 0.929 & 0.767 & 0.810 \\
\hline \multirow{4}{*}{ Pseudo-second-order } & $k_{2}\left(\mathrm{~g} \cdot \mathrm{mg}^{-1} \cdot \mathrm{h}^{-1}\right)$ & 0.503 & 0.150 & 0.171 \\
\hline & $q_{e, \mathrm{cal}}\left(\mathrm{mg} \cdot \mathrm{g}^{-1}\right)$ & 1.269 & 3.393 & 4.214 \\
\hline & $v_{0}\left(\mathrm{mg} \cdot \mathrm{g}^{-1} \cdot \mathrm{h}^{-1}\right)$ & 0.810 & 1.732 & 3.042 \\
\hline & $R^{2}$ & 0.999 & 0.999 & 0.999 \\
\hline \multirow{9}{*}{ Intraparticle diffusion } & $K_{w 1}\left(\mathrm{mg} \cdot \mathrm{g}^{-1} \cdot \mathrm{h}^{1 / 2}\right)$ & 0.526 & 1.332 & 2.088 \\
\hline & $C_{1}$ & 0.085 & 0.198 & 0.358 \\
\hline & $R^{2}$ & 0.999 & 0.999 & 0.999 \\
\hline & $K_{w 2}\left(\mathrm{mg} \cdot \mathrm{g}^{-1} \cdot \mathrm{h}^{1 / 2}\right)$ & 0.330 & 0.811 & 0.829 \\
\hline & $\mathrm{C}_{2}$ & 0.228 & 0.580 & 1.391 \\
\hline & $R^{2}$ & 0.885 & 0.948 & 0.969 \\
\hline & $K_{w 3}\left(\mathrm{mg} \cdot \mathrm{g}^{-1} \cdot \mathrm{h}^{1 / 2}\right)$ & 0.036 & 0.109 & 0.112 \\
\hline & $C_{3}$ & 0.992 & 2.346 & 3.356 \\
\hline & $R^{2}$ & 0.882 & 0.936 & 0.881 \\
\hline
\end{tabular}

had higher adsorption capacity than that of AA and AC. Particularly, the adsorption capacity of As (III) on Ce-Al-Fe adsorbent with $\mathrm{Al} / \mathrm{Fe} / \mathrm{Ce}=2: 1: 0.5$ was up to $8.18 \mathrm{mg} \cdot \mathrm{g}^{-1}$ and As (III) removal percent of $82 \%$ was achieved.

The adsorption capacity was improved as $\mathrm{Ce} /(\mathrm{Al}+\mathrm{Fe})$ molar ratio increases from $0.2 / 3$ to $0.5 / 3$, while it decreased as $\mathrm{Ce} /(\mathrm{Al}+\mathrm{Fe})$ molar ratio further increases to $1.5 / 3$. The maximum adsorption capacity $\left(8.18 \mathrm{mg} \cdot \mathrm{g}^{-1}\right)$ was achieved at $\mathrm{Al} / \mathrm{Fe} / \mathrm{Ce}$ molar ratio of $2: 1: 0.5$.

3.3. Adsorption Kinetics. At initial As (III) concentration of 3,8 , and $10 \mathrm{mg} \cdot \mathrm{L}^{-1}$, As (III) adsorption kinetics on the adsorbent were shown in Figure 3.

The adsorption capacity presented the same trend of variability at different initial concentration. It can be found that $\mathrm{Ce}-\mathrm{Al}-\mathrm{Fe}$ trimetal oxide adsorbent had a high adsorption rate in the first $7 \mathrm{~h}$ and the adsorption equilibrium was reached at $24 \mathrm{~h}$. When contact time increased from $24 \mathrm{~h}$ to $48 \mathrm{~h}$, the adsorption capacity for As (III) showed no significant change. The equilibrium adsorption capacities of As (III) were $1.225,3.273$, and $4.097 \mathrm{mg} \cdot \mathrm{g}^{-1}$ when initial As (III) concentrations were 3,8 , and $10 \mathrm{mg} \cdot \mathrm{L}^{-1}$, respectively.

To further understand the rate-controlling step and adsorption behavior of Ce-Al-Fe adsorbent for As (III), the adsorption kinetic data were fitted by the pseudo-secondorder and pseudo-first-order models, which are usually expressed as [34]

$$
\begin{aligned}
\frac{t}{q_{t}} & =\frac{1}{k_{2} q_{e}^{2}}+\frac{t}{q_{e}}, \\
\ln \left(q_{e}-q_{t}\right) & =\ln q_{e}-k_{1} t,
\end{aligned}
$$

where $q_{e}\left(\mathrm{mg} \cdot \mathrm{g}^{-1}\right)$ and $q_{t}\left(\mathrm{mg} \cdot \mathrm{g}^{-1}\right)$ are As (III) adsorption capacity at equilibrium and time $t(\mathrm{~h}), k_{1}\left(\mathrm{~h}^{-1}\right)$, and $k_{2}$ $\left(\mathrm{g} \cdot \mathrm{mg}^{-1} \cdot \mathrm{h}^{-1}\right)$ are the rate constants. The adsorption rate $v_{0}=$

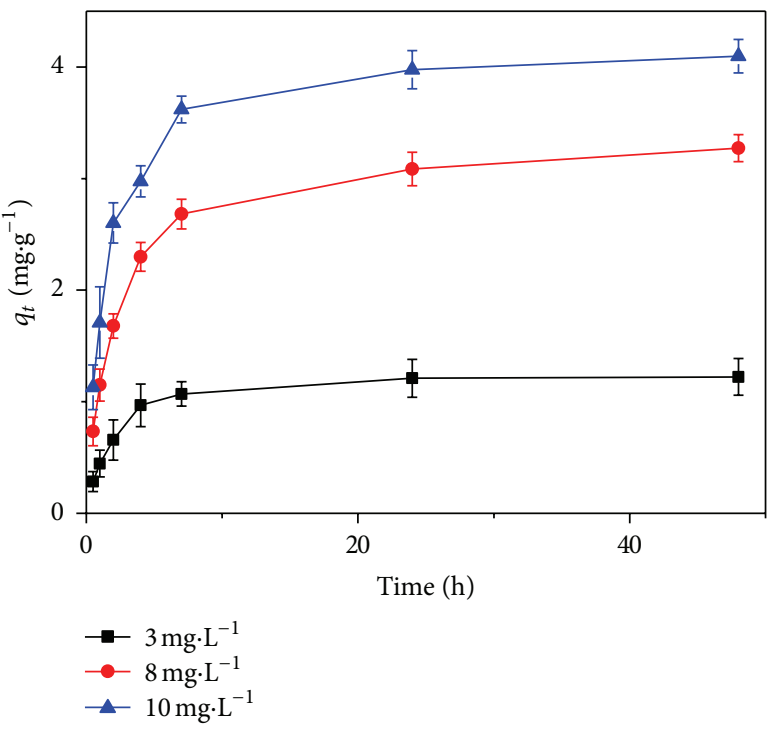

Figure 3: As (III) adsorption capacity onto Ce-Al-Fe trimetal oxide adsorbent for different contact time and initial As (III) concentrations ( $\mathrm{pH}=7.0$, initial As (III) concentration $=3,8$, and $10 \mathrm{mg} \cdot \mathrm{L}^{-1}$, the temperature $=25 \pm 1^{\circ} \mathrm{C}$, and adsorbent dosage $=$ $\left.2 \mathrm{~g} \cdot \mathrm{L}^{-1}\right)$.

$k_{2} q_{e}^{2}\left(\mathrm{mg} \cdot \mathrm{g}^{-1} \cdot \mathrm{h}^{-1}\right)$ can be considered to be the rate as $t$ approaches 0 .

For the adsorption process, the rate limiting step was studied by the intraparticle diffusion model, which is expressed in [35]

$$
q_{t}=K_{w} t^{1 / 2}+C,
$$

where $C$ is the intercept and $K_{w}\left(\mathrm{mg} \cdot \mathrm{g}^{-1} \cdot \mathrm{h}^{1 / 2}\right)$ is the rate constant.

The fitted curves of the three models and the fitting parameters are shown in Figure 4 and Table 1, respectively. 

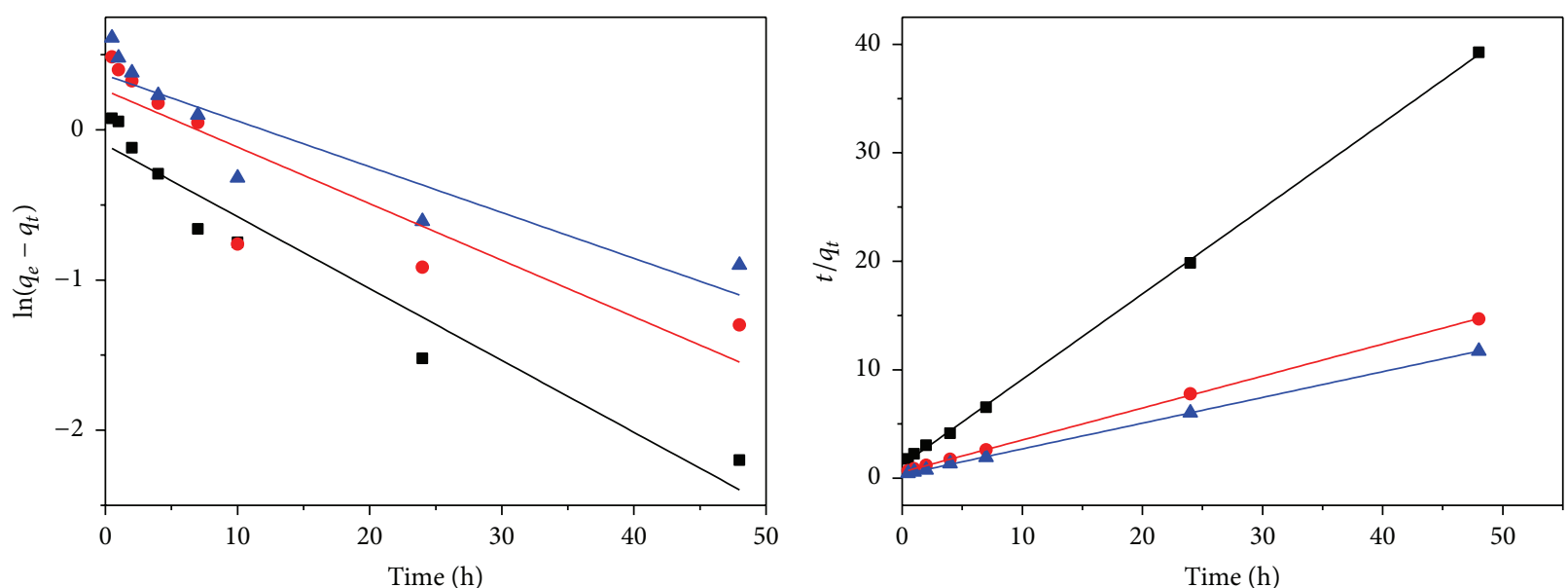

- $3 \mathrm{mg} \cdot \mathrm{L}^{-1}$

- $8 \mathrm{mg} \cdot \mathrm{L}^{-1}$

- $3 \mathrm{mg} \cdot \mathrm{L}^{-1}$

- $8 \mathrm{mg} \cdot \mathrm{L}^{-1}$

\ $10 \mathrm{mg} \cdot \mathrm{L}^{-1}$

- $10 \mathrm{mg} \cdot \mathrm{L}^{-1}$

(a)

(b)

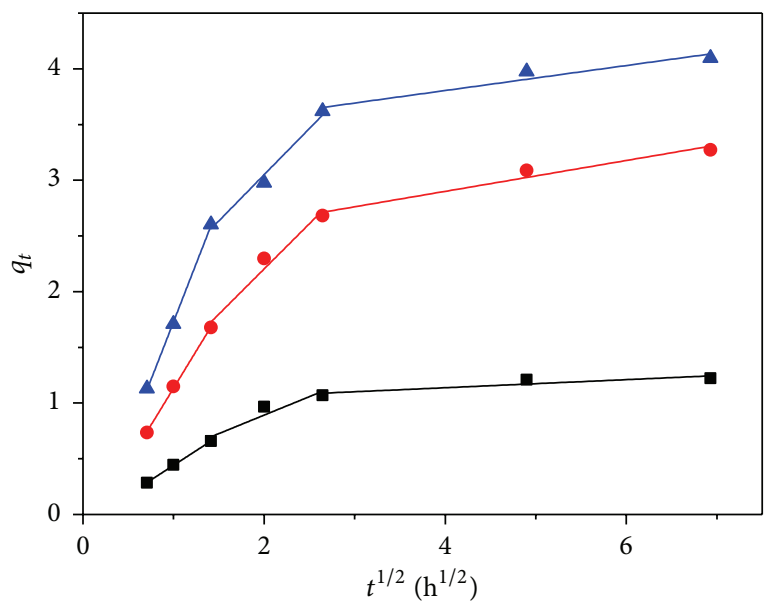
- $3 \mathrm{mg} \cdot \mathrm{L}^{-1}$
- $8 \mathrm{mg} \cdot \mathrm{L}^{-1}$
- $10 \mathrm{mg} \cdot \mathrm{L}^{-1}$

(c)

FIgURE 4: The linearized adsorption kinetics of As (III) on Ce-Al-Fe trimetal oxide adsorbent ((a) pseudo-first-order kinetics model, (b) pseudo-second-order kinetics model, and (c) intraparticle diffusion model).

The high correlation coefficient $\left(R^{2}\right)$ and the good agreement between the theoretical adsorption capacity $\left(q_{e, \text { cal }}\right)$ and the experimental adsorption capacity $\left(q_{e, \text { exp }}\right)$ indicated that As (III) adsorption on Ce-Al-Fe trimetal oxide adsorbent was fitted well by the pseudo-second-order model. This suggested that the adsorption process might be chemisorption [36-38]. The adsorption rate $\left(v_{0}\right)$ increased with initial increasing As (III) concentration due to increasing driving force.

As shown in Figure 4(c), the intraparticle diffusion kinetic curves presented three linear stages, indicating that the intraparticle diffusion may be one of the rate-controlling steps. The fitted values of $C$ values were not zero, giving an indication of the boundary layer thickness. At different As (III) concentration, the diffusion rate constant presents order of $k_{1}>k_{2}>k_{3}$. This result suggested that As (III) was adsorbed quickly onto the exterior surface of Ce-Al-Fe trimetal oxide adsorbent at first. Afterwards, the adsorption on the external surface reached equilibrium and As (III) entered into the adsorbent pores slowly. Then, on the interior surface, As (III) adsorption reached equilibrium.

3.4. Adsorption Isotherm. At 20,30 , and $40^{\circ} \mathrm{C}$, As (III) adsorption isotherm was investigated with As (III) concentration of $1,10,30,40$, and $50 \mathrm{mg} \cdot \mathrm{L}^{-1}$. Figure 5 presented curves of the adsorption capacity $\left(q_{e}, \mathrm{mg} \cdot \mathrm{g}^{-1}\right)$ versus As (III) equilibrium concentration $\left(C_{e}, \mathrm{mg} \cdot \mathrm{L}^{-1}\right)$. The adsorption capacity increased as temperature and As (III) concentrations increase. 
TABLE 2: The parameters of Langmuir and Freundlich models at different temperatures.

\begin{tabular}{|c|c|c|c|c|}
\hline \multirow{2}{*}{ Adsorption isotherm models } & \multirow{2}{*}{ Parameters } & \multicolumn{3}{|c|}{ Temperature $\left({ }^{\circ} \mathrm{C}\right)$} \\
\hline & & 20 & 30 & 40 \\
\hline \multirow{3}{*}{ Langmuir isotherm } & $Q_{\max }\left(m g \cdot g^{-1}\right)$ & 44.385 & 41.580 & 32.787 \\
\hline & $b\left(\mathrm{~L} \cdot \mathrm{mg}^{-1}\right)$ & 0.051 & 0.060 & 0.084 \\
\hline & $R^{2}$ & 0.840 & 0.856 & 0.840 \\
\hline \multirow{3}{*}{ Freundlich isotherm } & $K_{F}\left(\mathrm{mg}^{1-1 / n} \cdot \mathrm{L}^{1 / n} \cdot \mathrm{g}^{-1}\right)$ & 2.005 & 2.186 & 2.427 \\
\hline & $n$ & 1.121 & 1.115 & 1.128 \\
\hline & $R^{2}$ & 0.999 & 0.996 & 0.995 \\
\hline
\end{tabular}

TABLE 3: The thermodynamic parameters for the adsorption of As (III) on the adsorbent.

\begin{tabular}{lccc}
\hline Temperature $(\mathrm{K})$ & $\Delta G\left(\mathrm{~kJ} \mathrm{~mol}^{-1}\right)$ & $\begin{array}{c}\text { Thermodynamic parameters } \\
\left.\Delta H(\mathrm{~kJ} \mathrm{~mol})^{-1}\right)\end{array}$ & $\Delta S\left(\mathrm{~J} \mathrm{~mol}^{-1} \mathrm{~K}^{-1}\right)$ \\
\hline 293.15 & $-1.695 \pm 0.24$ & \\
303.15 & $-1.970 \pm 0.32$ & $7.278 \pm 0.45$ & $30.580 \pm 2.03$ \\
313.15 & $-2.308 \pm 0.19$ & & \\
\hline
\end{tabular}

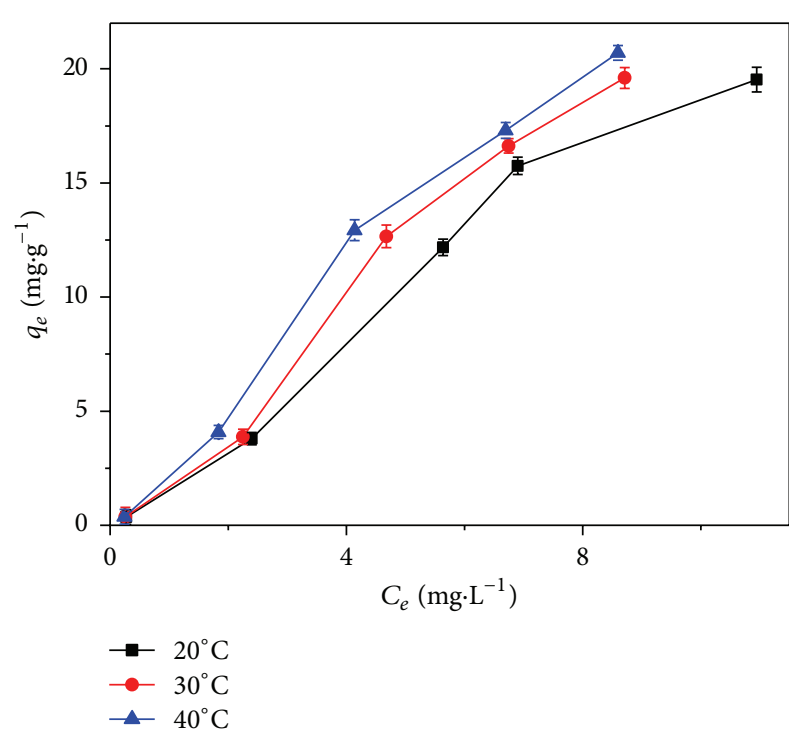

FIgURE 5: Adsorption isotherm of As (III) on Ce-Al-Fe trimetal oxide adsorbent at different temperature $(\mathrm{pH}=7.0$, initial concentration of As (III) $=1,10,30,40$, and $50 \mathrm{mg} \cdot \mathrm{L}^{-1}$, and adsorbent dosage $\left.=0.2 \mathrm{~g} \cdot \mathrm{L}^{-1}\right)$.

In order to express the interaction between the adsorbents and adsorbates, adsorption isothermal models including the Langmuir and Freundlich models were applied to investigate the adsorption process. The Langmuir isotherm model assumed that the solid surface is uniform with a monolayer adsorption and no interactions exist between molecules adsorbed [39]. The Freundlich isotherm model assumes multilayer adsorption on heterogeneous surfaces. The Freundlich and Langmuir isotherm model can be represented by $[39,40]$

$$
\begin{aligned}
\ln q_{e} & =\ln K_{F}+\frac{1}{n} \ln C_{e}, \\
\frac{C_{e}}{q_{e}} & =\frac{C_{e}}{Q_{\max }}+\frac{1}{b Q_{\max }},
\end{aligned}
$$

where $n$ and $K_{F}\left(\mathrm{mg}^{1-1 / n} \cdot \mathrm{L}^{1 / n} \cdot \mathrm{g}^{-1}\right)$ are the adsorption intensity and the constants. $Q_{\max }\left(\mathrm{mg} \cdot \mathrm{g}^{-1}\right)$ and $b\left(\mathrm{~L} \cdot \mathrm{mg}^{-1}\right)$ are the maximum adsorption amount and the constant related to the binding sites affinity. The results are shown in Figure 6 and Table 2.

The Freundlich isotherm model well scribed the adsorption process, indicated by the high correlation coefficients $\left(R^{2}\right.$ $=0.999,0.996$, and 0.995 , resp.) as compared to the Langmuir isotherm model $\left(R^{2}=0.840,0.856\right.$, and 0.840 , resp.). This result suggested that As (III) might be adsorbed on the adsorbent surface in the multilayer coverage. $n$ calculated values were between 1.115 and 1.128 at 20,30 , and $40^{\circ} \mathrm{C}$, indicating that As (III) was favorably adsorbed by Ce-Al-Fe adsorbent studied.

3.5. Adsorption Thermodynamics. To evaluate the nature of the adsorption, three thermodynamic parameters including entropy change $\left(\Delta H, \mathrm{~kJ} \cdot \mathrm{mol}^{-1}\right)$, enthalpy change $(\Delta S$, $\left.\mathrm{kJ} \cdot \mathrm{mol}^{-1}\right)$, and standard free energy $\left(\Delta G, \mathrm{~kJ} \cdot \mathrm{mol}^{-1}\right)$, which present the inherent energetic changes, were expressed in $[41,42]$

$$
\begin{aligned}
\Delta G & =R T \ln K_{F}=\Delta H-\Delta S, \\
\ln K_{F} & =-\frac{\Delta H}{R T}+\frac{\Delta S}{R},
\end{aligned}
$$

where $K_{F}\left(\mathrm{mg}^{1-1 / n} \cdot \mathrm{L}^{1 / n} \cdot \mathrm{g}^{-1}\right)$ was the Freundlich adsorption equilibrium constant and $R\left(8.314 \mathrm{~J} \cdot \mathrm{mol}^{-1} \cdot \mathrm{K}^{-1}\right)$ and $T(\mathrm{~K})$ are the gas constant and the absolute temperature in Kevin. $\Delta H$ and $\Delta S$ can be determined from the intercept and slope of the linear plot of $\ln K_{F}$ versus $1 / T$. Table 3 listed the thermodynamic parameters.

$\Delta G$ decreased as temperature increases, which indicated that adsorption process of As (III) is more favorable at higher temperatures [43]. $\Delta G$ values were negative, which suggested the thermodynamic favorability and spontaneity of As (III) adsorption. The positive $\Delta H$ values confirmed 


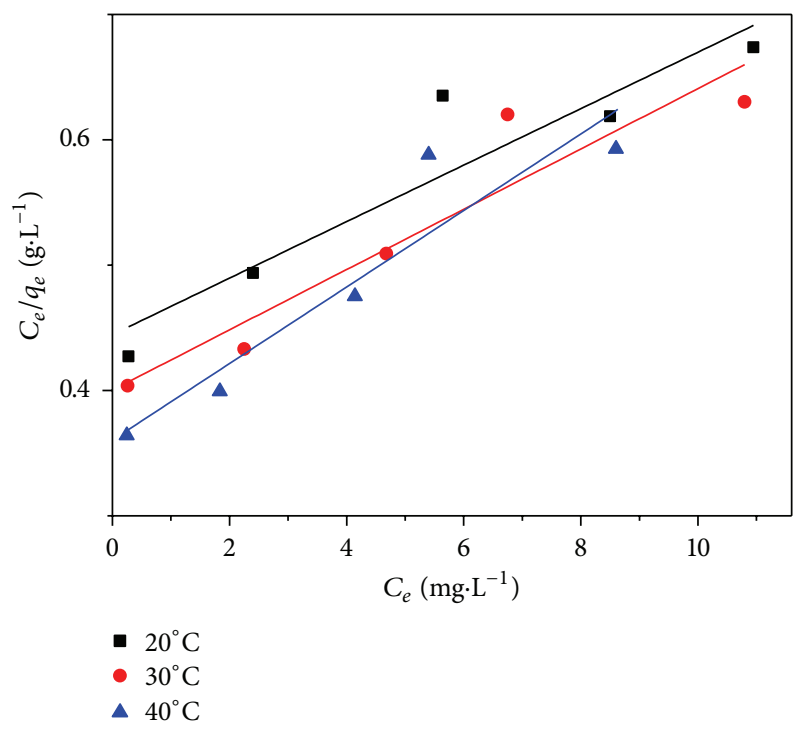

(a)

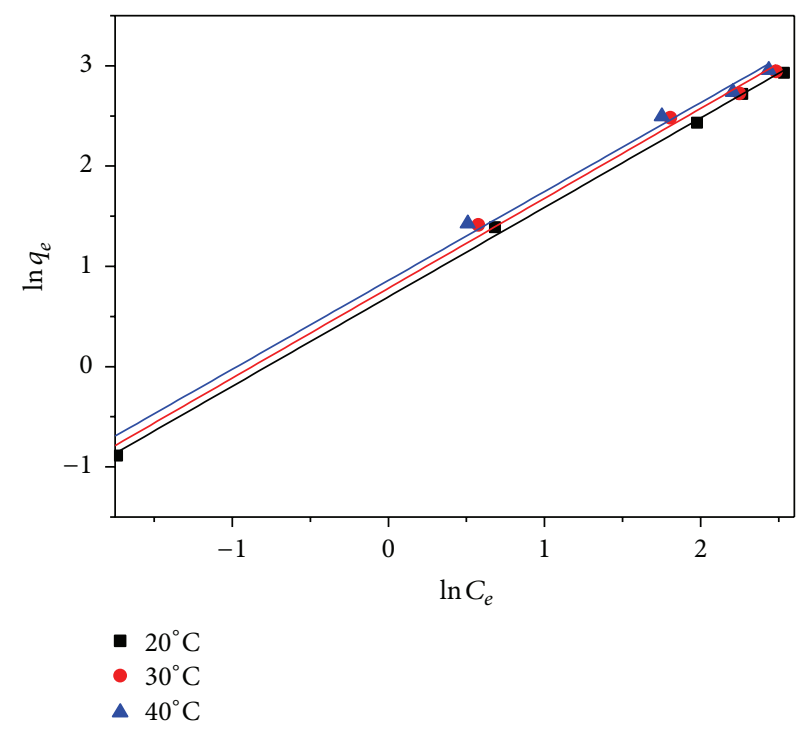

(b)

Figure 6: The linearized adsorption isotherm of As (III) on Ce-Al-Fe trimetal oxide adsorbent ((a) Langmuir isotherm model and (b) Freundlich isotherm model).

an endothermic nature of As (III) adsorption on Ce-Al-Fe trimetal oxide adsorbent. In addition, the positive $\Delta S$ values indicated As (III) adsorption process at the solid/solution interface presented an increasing randomness [44].

\section{Conclusions}

Ce-Al-Fe adsorbent with tiny uniformly distributed pores has been developed for As (III) removal.

At initial As (III) concentration of 3, 8, and $10 \mathrm{mg} \cdot \mathrm{L}^{-1}$, the maximum adsorption capacities of As (III) were 1.48, 3.73 , and $5.12 \mathrm{mg} \cdot \mathrm{g}^{-1}$, respectively. Kinetics of fitting by the pseudo-second-order model with $R^{2}$ higher than 0.998 suggested that the chemisorption was rate-determining process. The adsorption data of Ce-Al-Fe adsorbent can be expressed well by the Freundlich isotherm with $R^{2}$ greater than 0.996 . The negative $\Delta G$, positive $\Delta S$, and positive $\Delta H$ suggested that As (III) adsorption nature was exothermic, spontaneous, and increasing randomness on the interface of water and adsorbent.

The adsorption mechanism can be interpreted as chemisorption with multilayer adsorption of As (III) on the adsorbent surface.

\section{Competing Interests}

The authors declare that they have no competing interests.

\section{Acknowledgments}

The work was financially supported by the Special Foundation of Shandong Province Financial Department and
Environmental Protection Bureau under Grant no. SDZS2012-SHBT01, Shandong Natural Science Foundation under Grant no. ZR2012EEQ024, and Taishan Scholar Foundation.

\section{References}

[1] A. Bhatnagar, W. Hogland, M. Marques, and M. Sillanpää, "An overview of the modification methods of activated carbon for its water treatment applications," Chemical Engineering Journal, vol. 219, pp. 499-511, 2013.

[2] D. Chauhan, J. Dwivedi, and N. Sankararamakrishnan, "Novel chitosan/PVA/zerovalent iron biopolymeric nanofibers with enhanced arsenic removal applications," Environmental Science and Pollution Research, vol. 21, no. 15, pp. 9430-9442, 2014.

[3] X. Wu, X. Tan, S. Yang et al., "Coexistence of adsorption and coagulation processes of both arsenate and NOM from contaminated groundwater by nanocrystallined $\mathrm{Mg} / \mathrm{Al}$ layered double hydroxides," Water Research, vol. 47, no. 12, pp. 41594168, 2013.

[4] M. Kobya, E. Demirbas, U. Gebologlu, M. S. Oncel, and Y. Yildirim, "Optimization of arsenic removal from drinking water by electrocoagulation batch process using response surface methodology," Desalination and Water Treatment, vol. 51, no. 34-36, pp. 6676-6687, 2013.

[5] A. K. Meher, S. Das, S. Rayalu, and A. Bansiwal, "Enhanced arsenic removal from drinking water by iron-enriched aluminosilicate adsorbent prepared from fly ash," Desalination and Water Treatment, 2015.

[6] M. C. S. Faria, R. S. Rosemberg, C. A. Bomfeti et al., "Arsenic removal from contaminated water by ultrafine $\delta$-FeOOH adsorbents," Chemical Engineering Journal, vol. 237, pp. 47-54, 2014.

[7] M.-L. Chen, Y. Sun, C.-B. Huo, C. Liu, and J.-H. Wang, "Akaganeite decorated graphene oxide composite for arsenic adsorption/removal and its proconcentration at ultra-trace level," Chemosphere, vol. 130, pp. 52-58, 2015. 
[8] M. Mosaferi, S. Nemati, A. Khataee, S. Nasseri, and A. A. Hashemi, "Removal of arsenic (III, V) from aqueous solution by nanoscale zero-valent iron stabilized with starch and carboxymethyl cellulose," Journal of Environmental Health Science and Engineering, vol. 12, no. 1, article 74, 2014.

[9] M. Rahim and M. R. H. M. Haris, "Application of biopolymer composites in arsenic removal from aqueous medium: a review," Journal of Radiation Research and Applied Sciences, vol. 8, no. 2, pp. 255-263, 2015.

[10] Y.-J. Shih, R.-L. Huang, and Y.-H. Huang, "Adsorptive removal of arsenic using a novel akhtenskite coated waste goethite," Journal of Cleaner Production, vol. 87, no. 1, pp. 897-905, 2015.

[11] J. Li, Y.-N. Wu, Z. Li et al., "Zeolitic imidazolate framework-8 with high efficiency in trace arsenate adsorption and removal from water," The Journal of Physical Chemistry C, vol. 118, no. 47, pp. 27382-27387, 2014.

[12] S. Bordoloi, S. K. Nath, S. Gogoi, and R. K. Dutta, "Arsenic and iron removal from groundwater by oxidation-coagulation at optimized pH: laboratory and field studies," Journal of Hazardous Materials, vol. 260, pp. 618-626, 2013.

[13] A. Dominguez-Ramos, K. Chavan, V. García et al., "Arsenic removal from natural waters by adsorption or ion exchange: an environmental sustainability assessment," Industrial \& Engineering Chemistry Research, vol. 53, no. 49, pp. 18920-18927, 2014.

[14] T. A. Vu, G. H. Le, C. D. Dao et al., "Arsenic removal from aqueous solutions by adsorption using novel MIL-53(Fe) as a highly efficient adsorbent," RSC Advances, vol. 5, no. 7, pp. 52615268, 2015.

[15] Y.-S. Han, A. H. Demond, T. J. Gallegos, and K. F. Hayes, "Dependence of particle concentration effect on $\mathrm{pH}$ and redox for arsenic removal by FeS-coated sand under anoxic conditions," Chemosphere, vol. 134, pp. 499-503, 2015.

[16] J. V. Flores-Cano, R. Leyva-Ramos, F. Carrasco-Marin, A. Aragón-Piña, J. J. Salazar-Rabago, and S. Leyva-Ramos, "Adsorption mechanism of Chromium(III) from water solution on bone char: effect of operating conditions," Adsorption, vol. 22, no. 3, pp. 297-308, 2016.

[17] A. D. Abid, M. Kanematsu, T. M. Young, and I. M. Kennedy, "Arsenic removal from water using flame-synthesized iron oxide nanoparticles with variable oxidation states," Aerosol Science and Technology, vol. 47, no. 2, pp. 169-176, 2013.

[18] M. R. Lescano, C. Passaliá, C. S. Zalazar, and R. J. Brandi, "Arsenic sorption onto titanium dioxide, granular ferric hydroxide and activated alumina: batch and dynamic studies," Journal of Environmental Science and Health, Part A: Toxic/Hazardous Substances and Environmental Engineering, vol. 50, no. 4, pp. 424-431, 2015.

[19] T. Mishra and D. K. Mahato, "A comparative study on enhanced $\operatorname{arsenic}(\mathrm{V})$ and arsenic(III) removal by iron oxide and manganese oxide pillared clays from ground water," Journal of Environmental Chemical Engineering, vol. 4, no. 1, pp. 12241230, 2016.

[20] T. Wen, X. Wu, X. Tan, X. Wang, and A. Xu, "One-pot synthesis of water-swellable $\mathrm{Mg}$-Al layered double hydroxides and graphene oxide nanocomposites for efficient removal of As(V) from aqueous solutions," ACS Applied Materials and Interfaces, vol. 5, no. 8, pp. 3304-3311, 2013.

[21] S. Liu, S. Kang, G. Wang, H. Zhao, and W. Cai, "Micro/nanostructured porous Fe-Ni binary oxide and its enhanced arsenic adsorption performances," Journal of Colloid and Interface Science, vol. 458, pp. 94-102, 2015.
[22] G. Zhang, Z. Ren, X. Zhang, and J. Chen, "Nanostructured iron (III)-copper (II) binary oxide: a novel adsorbent for enhanced arsenic removal from aqueous solutions," Water Research, vol. 47, no. 12, pp. 4022-4031, 2013.

[23] K.-H. Goh, T.-T. Lim, and Z. Dong, "Enhanced arsenic removal by hydrothermally treated nanocrystalline MG/AL layered double hydroxide with nitrate intercalation," Environmental Science \& Technology, vol. 43, no. 7, pp. 2537-2543, 2009.

[24] J. A. Muñoz, A. Gonzalo, and M. Valiente, "Arsenic adsorption by Fe(III)-loaded open-celled cellulose sponge. Thermodynamic and selectivity aspects," Environmental Science \& Technology, vol. 36, no. 15, pp. 3405-3411, 2002.

[25] I. Akin, G. Arslan, A. Tor, Y. Cengeloglu, and M. Ersoz, "Removal of arsenate $[\mathrm{As}(\mathrm{V})]$ and arsenite [As(III)] from water by SWHR and BW-30 reverse osmosis," Desalination, vol. 281, pp. 88-92, 2011.

[26] L. Yu, Y. Ma, C. N. Ong, J. Xie, and Y. Liu, "Rapid adsorption removal of arsenate by hydrous cerium oxide-graphene composite," RSC Advances, vol. 5, no. 80, pp. 64983-64990, 2015.

[27] D. Tang and G. Zhang, "Efficient removal of fluoride by hierarchical Ce-Fe bimetal oxides adsorbent: thermodynamics, kinetics and mechanism," Chemical Engineering Journal, vol. 283, pp. 721-729, 2016.

[28] Y. Su, W. Yang, W. Sun, Q. Li, and J. K. Shang, "Synthesis of mesoporous cerium-zirconium binary oxide nanoadsorbents by a solvothermal process and their effective adsorption of phosphate from water," Chemical Engineering Journal, vol. 268, pp. 270-279, 2015.

[29] T. Parangi, B. Wani, and U. Chudasama, "Sorption and separation study of heavy metal ions using cerium phosphate: a cation exchanger," Desalination and Water Treatment, vol. 57, no. 14, pp. 6443-6451, 2016.

[30] V. Kuroki, G. E. Bosco, P. S. Fadini, A. A. Mozeto, A. R. Cestari, and W. A. Carvalho, "Use of a La(III)-modified bentonite for effective phosphate removal from aqueous media," Journal of Hazardous Materials, vol. 274, pp. 124-131, 2014.

[31] G. K. Reddy, J. He, S. W. Thiel, N. G. Pinto, and P. G. Smirniotis, "Sulfur-tolerant Mn-Ce-Ti sorbents for elemental mercury removal from flue gas: mechanistic investigation by XPS," Journal of Physical Chemistry C, vol. 119, no. 16, pp. 86348644, 2015.

[32] Y. Li, X. Cai, J. Guo, S. Zhou, and P. Na, "Fe/Ti co-pillared clay for enhanced arsenite removal and photo oxidation under UV irradiation," Applied Surface Science, vol. 324, pp. 179-187, 2015.

[33] B. Chen, Z. Zhu, Y. Guo, Y. Qiu, and J. Zhao, "Facile synthesis of mesoporous $\mathrm{Ce}-\mathrm{Fe}$ bimetal oxide and its enhanced adsorption of arsenate from aqueous solutions," Journal of Colloid and Interface Science, vol. 398, pp. 142-151, 2013.

[34] Y. S. Ho and G. McKay, "Kinetic models for the sorption of dye from aqueous solution by wood," Process Safety and Environmental Protection, vol. 76, no. 2, pp. 183-191, 1998.

[35] G. H. Graaf, H. Scholtens, E. J. Stamhuis, and A. A. C. M. Beenackers, "Intra-particle diffusion limitations in lowpressure methanol synthesis," Chemical Engineering Science, vol. 45, no. 4, pp. 773-783, 1990.

[36] P. Ilgin and A. Gur, "Synthesis and characterization of a new fast swelling poly(EPMA-co-METAC) as superabsorbent polymer for anionic dye absorbent," Iranian Polymer Journal, vol. 24, no. 2, pp. 149-159, 2015.

[37] H. H. Najafabadi, M. Irani, L. Roshanfekr Rad, A. Heydari Haratameh, and I. Haririan, "Removal of $\mathrm{Cu}^{2+}, \mathrm{Pb}^{2+}$ and 
$\mathrm{Cr}^{6+}$ from aqueous solutions using a chitosan/graphene oxide composite nanofibrous adsorbent," RSC Advances, vol. 5, no. 21, pp. 16532-16539, 2015.

[38] F. Luo, J. L. Chen, L. L. Dang et al., "High-performance $\mathrm{Hg}^{2+}$ removal from ultra-low-concentration aqueous solution using both acylamide- and hydroxyl-functionalized metal-organic framework," Journal of Materials Chemistry A, vol. 3, no. 18, pp. 9616-9620, 2015.

[39] I. Langmuir, "The adsorption of gases on plane surfaces of glass, mica and platinum," Journal of the American Chemical Society, vol. 40, no. 9, pp. 1361-1403, 1918.

[40] H. Freundlich, "Over the adsorption in solution," The Journal of Physical Chemistry, vol. 57, no. 385, pp. 462-470, 1906.

[41] C. Santhosh, P. Kollu, S. Felix, V. Velmurugan, S. K. Jeong, and A. N. Grace, " $\mathrm{CoFe} \mathrm{O}_{4}$ and $\mathrm{NiFe}_{2} \mathrm{O}_{4} @$ graphene adsorbents for heavy metal ions-kinetic and thermodynamic analysis," RSC Advances, vol. 5, no. 37, pp. 28965-28972, 2015.

[42] W.-T. Jiang, P.-H. Chang, Y. Tsai, and Z. Li, "Halloysite nanotubes as a carrier for the uptake of selected pharmaceuticals," Microporous and Mesoporous Materials, vol. 220, pp. 298-307, 2016.

[43] M. R. Yazdani, T. Tuutijärvi, A. Bhatnagar, and R. Vahala, "Adsorptive removal of $\operatorname{arsenic}(\mathrm{V})$ from aqueous phase by feldspars: kinetics, mechanism, and thermodynamic aspects of adsorption," Journal of Molecular Liquids, vol. 214, pp. 149-156, 2016.

[44] L. J. Kennedy, J. J. Vijaya, G. Sekaran, and K. Kayalvizhi, “Equilibrium, kinetic and thermodynamic studies on the adsorption of m-cresol onto micro- and mesoporous carbon," Journal of Hazardous Materials, vol. 149, no. 1, pp. 134-143, 2007. 

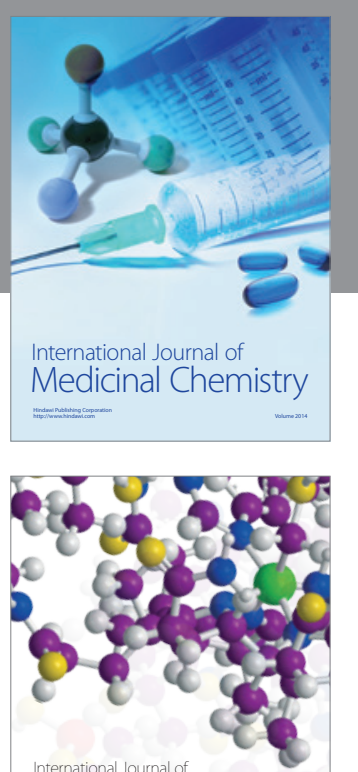

Carbohydrate Chemistry

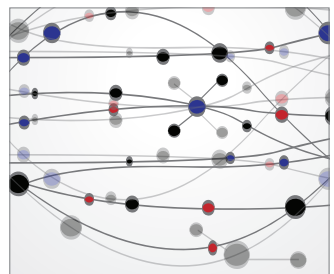

The Scientific World Journal
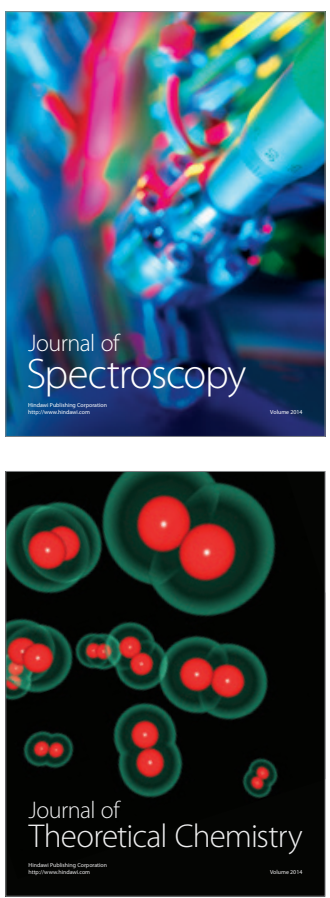
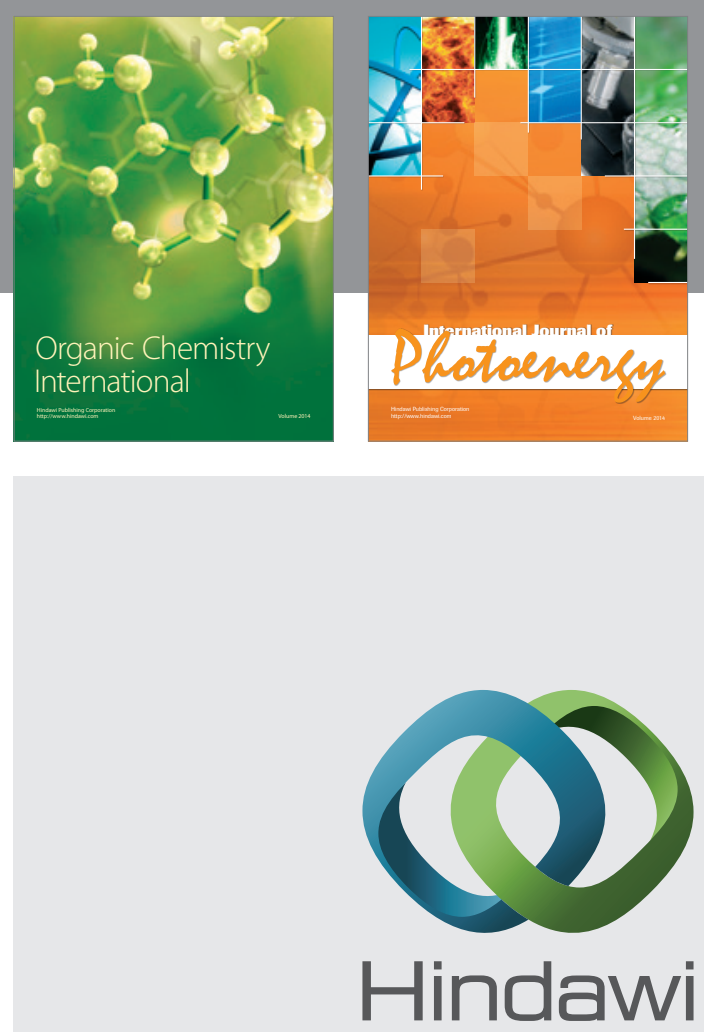

Submit your manuscripts at

http://www.hindawi.com

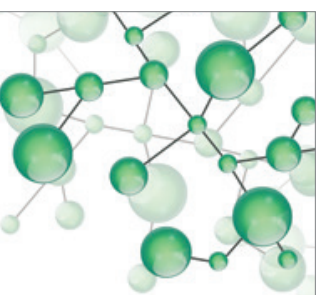

International Journal of

Inorganic Chemistry

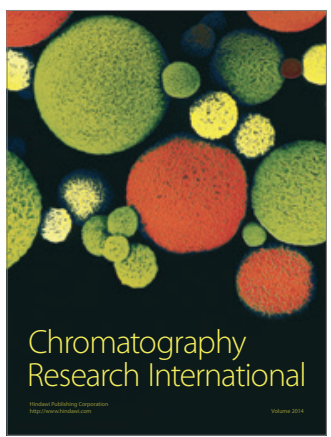

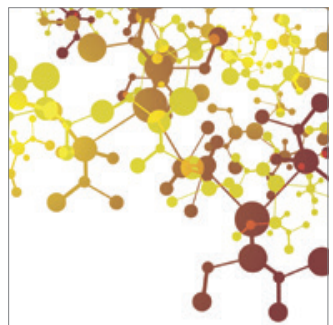

Applied Chemistry
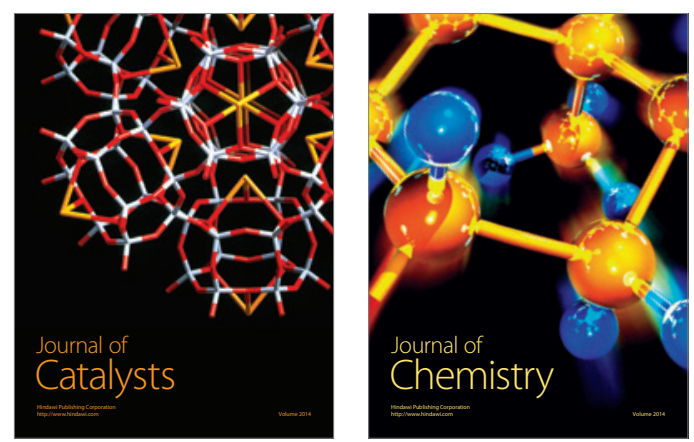
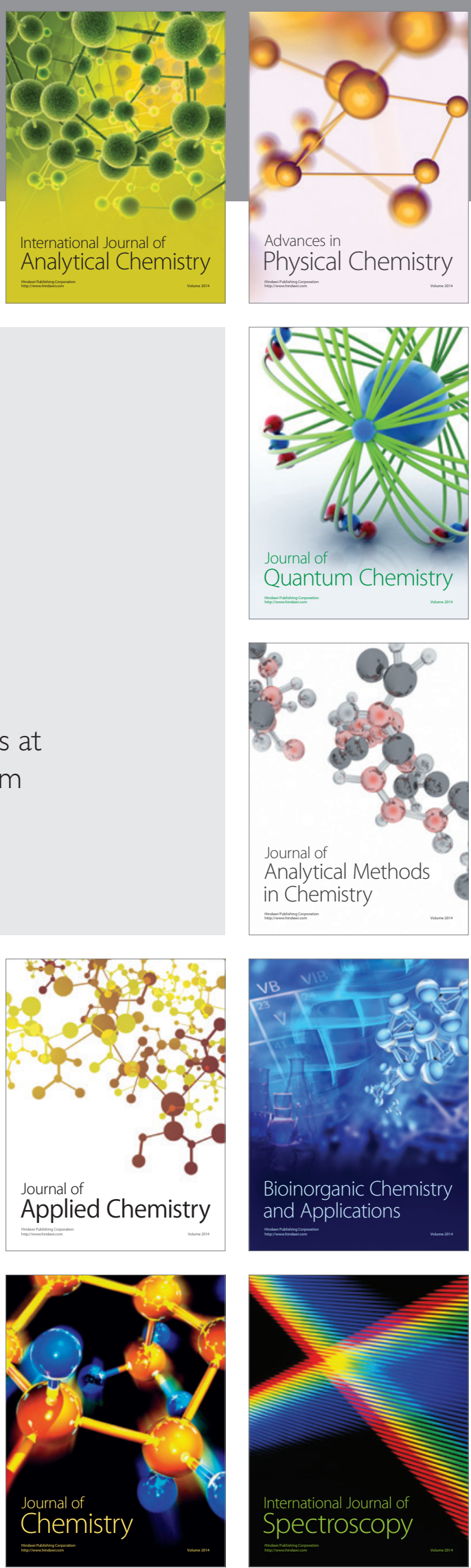